Н. М. Серединська, Т. А. Бухтіарова, Л. П. Бабенко, О. М. Величко

\title{
Модуляція протизапальної активності Кеторолаку за умов фармакодинамічної взаємодії з Гідазепамом й Амітриптиліном і структурно-динамічні властивості мембран еритроцитів на тлі больового синдрому
}

Державна установа «Інститут фармакології та токсикології Національної академії медичних наук України», м. Київ

Ключові слова: больовий синдром, Кеторолак, Гдазепам, Амітриптилін, протизапальна дія, мембрани еритроцитів

Фармакотерапія болю є однією з найактуальніших медико-соціальних проблем. За даними ВООЗ, больові відчуття становлять до $40 \%$ від усіх скарг під час звернень за медичною допомогою і, зрозуміло, потребують фармакологічної корекції $[1,2]$. Відомо, що для системної фармакотерапії больового синдрому використовують неопіоїдні та опіоїдні аналгетики, нестероїдні протизапальні засоби, а також ад'ювантні препарати [3-5].

Сучасна фармакотерапія болю базується на механізмах розвитку та відповідності між інтенсивністю болю та лікарським засобом, який застосовують [6, 7]. За інтенсивністю біль поділяють на слабкий, помірний, сильний і дуже сильний. Розподіл болю за інтенсивністю дає змогу застосовувати «ступінчату» тактику використання аналгетиків, а саме: у разі слабкого болю призначають ненаркотичні аналгетики, помірного - ненаркотичні аналгетики разом з нестероїдними протизапальними препаратами (НПЗП), у разі сильного та дуже сильного болю застосовують наркотичні засоби (морфін, промедол та ін.). Така тактика фармакотерапії болю дає змогу уникнути невиправданого призначення сильнодійних наркотиків тим пацієнтам, які їх не потребують, та не допустити можливих ускладнень і побічних ефектів.

Спостерігається тенденція до суттевого підвищення неопіоїдного компо-

(C) Колектив авторів, 2020 нента в фармакотерапії больового синдрому. Це не в останню чергу пов'язано з виявленням у НПЗП здатності пригнічувати відповідь таламуса на ноцицептивну стимуляцію та гальмувати розвиток вторинної гіпералгезії, тобто виявляти центральну аналгетичну дію [8]. Поширеність у клініці та резистентність під час лікування традиційними аналгетиками визначають проблему болю як актуальну для фундаментальної біомедичної науки, сучасної патофізіології та практичної охорони здоров'я, що потребує подальшого вивчення та пошуку нових підходів для іï вирішення. У світі постійно розробляють i впроваджують у клінічну практику нові ненаркотичні аналгезуючі засоби, здійснюють розроблення комбінованих лікарських засобів, зокрема, на основі неопіоїдних аналгетиків і нестероїдних протизапальних засобів, аналгетиків і холінергічних агентів та ін.

Одним із шляхів поліпшення знеболювання $є$ застосування ад'ювантних лікарських засобів. Під ад'ювантною (допоміжною) терапією розуміють додаткове використання лікарських засобів різних фармакотерапевтичних груп, дія яких спрямована на посилення ефективності аналгетиків або на корекцію їхніх побічних ефектів. Натепер існує навіть таке поняття, як «коаналгетики» або ад'ювантні аналгетики, під яким розуміють гетерогенну групу лікарських засобів із різноманітними механізмами дії, які забезпечують аналгезію в разі специфічних 
больових синдромів або нейтралізують побічну дію аналгетиків, що дає змогу підсилити їхній знеболювальний ефект. Така тактика фармакотерапії болю дає змогу уникнути невиправданого призначення сильнодіючих наркотичних засобів, не допустити можливих ускладнень і побічних ефектів або знизити дози «традиційних» аналгетиків.

Для дослідження ефективності щодо усунення гострого больового відчуття та запального набряку як ад'ювантні засоби обрано нейротропні препарати. Біль - не тільки симптом багатьох гострих і хронічних захворювань, але й складний психофізіологічний феномен, що залучає механізми регуляції та формування емоцій, моторні, гуморальні та гемодинамічні реакції [9]. Тому вибір препаратів зазначеної групи зумовлений тим, що больові синдроми різного генезу часто спричинюють психоемоційні та депресивні розлади $[10$, 11]. Нерідко за больового синдрому клініцисти вимушені застосовувати засоби групи транквілізаторів через те, що ці препарати, пригнічуючи діяльність ЦНС, знижують нервове напруження, дратівливість, усувають тривогу, занепокоєння, стабілізують психотичні розлади, знижуючи психічну напруженість. Основна властивість транквілізаторів - зниження психічної активності без порушення свідомості, фізичного, інтелектуального статусу пов'язана 3 пригніченням лімбічної системи мозку за рахунок посилення дії гальмівного медіатора ГАМК.

Крім зазначених ефектів, транквілізаторам притаманна міорелаксуюча дія, що зумовлена зниженням збудливості підкіркових областей головного мозку (лімбічна система, таламус, гіпоталамус), гальмівною дією на полісинаптичні спинальні рефлекси. Саме зазначені структури головного мозку відповідальні за здійснення емоційних реакцій (особливо, лімбічна система). Транквілізатори гальмують взаємодію між цими структурами та корою головного мозку.

Таким чином, транквілізатори усувають відчуття страху, тривоги, напруги, занепокоєння, що обгрунтовує їхне застосування для лікування різних пси- хогенних розладів: неврастенії, неврозів нав'язливих станів, істерії, психопатії, а також посттравматичних стресових розладів, що часто супроводжують біль [12]. Не виключено, що ефекти Гідазепаму залежать від активності різних нейромедіаторних систем, а сам транквілізатор у різних дозах може впливати на їхнє функціонування на тлі патології $[13,14]$. У гіпоталамусі Гідазепам знижує швидкість обороту серотоніну, а в стріатумі - вміст ГАМК. Гідазепам залежно від дози впливає на активність нейромедіаторних систем. У дозі 1 мг/ кг маси тіла тварин (миші) Гідазепам призводить до накопичення дофаміну та збільшує утилізацію серотоніну в гіпоталамусі. У дозі 10 мг/кг препарат сприяє зниженню вмісту норадреналіну, дофаміну та їхніх метаболітів, а також накопиченню серотоніну [15].

Крім того, транквілізатори можуть виявляти антиоксидантний ефект. За даними досліджень встановлено, що розвиток гострого больового синдрому в щурів спричинює активацію процесів перекисного окиснення ліпідів (ПОЛ) у сироватці, мембранах еритроцитів і гомогенаті спинного мозку тварин, а Гідазепаму притаманні антиоксидантні властивості за профілактично-лікувального введення [16]. Можна передбачити, що шляхом коригування процесів ПОЛ, а також, можливо, завдяки міорелаксуючій дії, регуляції нейромедіаторного статусу транквілізатори будуть виявляти знеболювальну дію.

Антиноцицептивні властивості антидепресантів, особливо в разі невропатичного та центрального болю, були виявлені після їхнього впровадження в психіатричну практику й доведені результатами низки сучасних контрольованих досліджень. Найкращі результати відзначено в разі застосування амітриптиліну, кломіпраміну й іміпраміну, тобто препаратів зі змішаним механізмом дії, що є потужними інгібіторами реаптейку як серотоніну, так і норадреналіну [6]. Завдяки такій властивості проявляється основний принцип дії, зокрема, Амітриптиліну зростання кількості норадреналіну, дофаміну та серотоніну внаслідок зменшення зворотного нейронального захва- 
ту мембранами пресинаптичних нейронів. У результаті інгібіції зворотного захвату збільшується вміст нейромедіаторів у синаптичних щілинах, нейрональні зв'язки покращуються, що призводить до нормалізації функціонування адренергічної та серотонінергічної систем. Амітриптилін впливає й на холінергічну медіацію, проявляючи антихолінергічну (М-холінолітичну) центральну та периферичну дію. Даному антидепресанту властиві антигістамінна та $\alpha$-адренолітична активність. Амітриптилін проявляє помірний аналгезуючий ефект за рахунок впливу на центральну нервову систему. Можна припустити, що означені механізми дії Амітриптиліну будуть позитивно впливати на ноцицептивну чутливість тварин за больового синдрому. Водночас здатність препарату викликати набряки може знижувати його протизапальний потенціал.

Слід усвідомлювати, що за умов комбінованого застосування ад'ювантних препаратів 3 «традиційними» аналгетиками може змінюватись ефективність та безпечність терапії через фармакодинамічну та/або фармакокінетичну взаємодію ліків різних фармакотерапевтичних груп. Тому питання взаємодії ліків, зокрема, транквілізаторів та антидепресантів з ненаркотичними аналгетиками, є цариною актуальних експериментальних і клінічних досліджень.

Відомо, що одними 3 перших мішеней лікарських засобів, як й інших фізіологічно активних субстанцій, що проникають в організм, $є$ протеїни плазми крові та мембрани клітин. Зважаючи на те, що під час розвитку гострого больового синдрому відбувається активація процесів ПОЛ, яка є одним із молекулярних механізмів порушення фізико-хімічних і структурно-функціональних властивостей мембран клітин, було доцільним вивчити стан структурно-динамічної організації мембран за комбінованого застосування препаратів різних фармакотерапевтичних груп для з'ясування механізмів їхньої взаємодії.

Мета дослідження - вивчити аналгезуючу, протизапальну та мембраностабілізуючу дію денного транквіліза- тора Гідазепаму та класичного трициклічного антидепресанту Амітриптиліну на тлі больового синдрому за умов комбінованого застосування 3 ненаркотичним аналгетиком Кеторолаком.

Матеріали та методи. Усі експериментальні процедури проводились відповідно до міжнародних вимог про гуманне ставлення до тварин, що окреслені Свропейською конвенцією про захист хребетних тварин (Страсбург, 1986), які використовуються в експериментальних та інших наукових цілях. Правила евтаназії та утилізації загиблих тварин відповідали вимогам умов доклінічної практики. Досліди здійснено на білих нелінійних статевозрілих щурах обох статей масою $(185,5 \pm 3,6)$ г. Гострий больовий синдром моделювали в тварин, рандомізованих за шістьма групами. До першої групи входили тварини ( $\mathrm{n}=16)$, яким під підошовний апоневроз задньої кінцівки було введено $2 \%$ водний розчин формаліну в об'ємі 0,1 мл. Тваринам другої $(\mathrm{n}=8)$ та третьої (n = 8) груп за 30 хв до моделювання больового синдрому вводили в шлунок у середніх терапевтичних дозах Гідазепам (0,02 мг/кг) і Амітриптилін (16 мг/кг маси тварини) відповідно. До четвертої групи віднесено щурів ( $\mathrm{n}=$ 16), яким за 30 хв до індукції больового процесу $2 \%$ розчином формаліну вводили в шлунок Кеторолак у середній терапевтичній дозі $-1,5$ мг/кг маси тіла. Дози для тварин визначені з урахуванням видової чутливості. До п'ятої групи віднесено тварин ( $\mathrm{n}=$ 8), яким за 30 хв до застосування формаліну в шлунок вводили Кеторолак і Гідазепам, по черзі, 3 інтервалом у 20 хв між препаратами. До шостої групи входили білі щури (n = 8), яким за 30 хв до застосування формаліну внутрішньошлунково (в/ш) вводили Кеторолак й Амітриптилін, по черзі, також з інтервалом у 20 хв між препаратами.

Больову реакцію тварин реєстрували шляхом визначення порога больової чутливості (ПБЧ) на установці «Planter test» (Ugo Basele, Італія) в інтактних щурів (тварини усіх груп, вихідні дані), а також через 4 год і через 24 год після введення флогогену. 
Протизапальну (протинабрякову) активність визначали за реєстрації об’єму ураженої стопи волюмометричним методом у ті самі терміни, коли досліджували ПБЧ.

Для встановлення одного з можливих механізмів протизапальної дії досліджуваних препаратів та їхніх комбінацій вивчали властивості поверхні мембран еритроцитів методом флуоресцентного зондування поверхневим аніонним зондом 1-(феніламіно)-8сульфонафталіном (АНС) [17]. Стан глибинних ланок мембрани досліджували за допомогою флуоресцентного зондування глибинним гідрофобним зондом піреном $\left(\mathrm{Cp}=5 \cdot 10^{-6}\right.$ моль/л) [18]. Вірогідність переносу енергії 3 молекул протеїнів (донорів) на флуоресцентний зонд пірен (акцептор) вивчали методом індуктивно-резонансного переносу енергії (IPПЕ). Параметр вірогідності IPПЕ W (ум. од.) визначали за формулою:

$$
\mathrm{W}=\left(\mathrm{F}_{0}-\mathrm{F}_{\mathrm{p}}\right) / \mathrm{F}_{0},
$$

де $\mathrm{F}_{0}$ i $\mathrm{F}_{\mathrm{p}}$ - флуоресценція суспензій еритроцитів за довжини хвилі 320 нм та $\lambda_{\text {зб }} 286$ нм до і після введення в суспензію пірену (флуориметр MPF-4).

Вибір мембрани еритроцитів як об'єкт дослідження був зумовлений тим, що їй притаманні загальні принципи молекулярної організації плазматичних мембран. Тому закономірності змін структури й функції мембрани еритроцитів із певною часткою корекції, зумовленої, насамперед, видовою специфічністю клітин, можуть бути екстрапольовані на інші мембранні системи. Крім цього, простота організації еритроцита як «деградованої» клітини дає можливість вивчати функціональні властивості плазматичної мембрани без перешкод, що накладаються внутрішньоклітинними мембранними утвореннями та органелами [19].

Результати та їх обговорення. Вихідне значення ПБЧ у білих щурів становило $(12,67 \pm 1,33)$ с. На тлі гіпералгезії формалінового генезу встановлено, що через 30 хв після введення формаліну в щурів знижувався ПБЧ на $71,6 \%$ порівняно до вихідного значення. Суттєве зниження ПБЧ відзначалося в усі подальші терміни спостереження (до 24 год від індукції запалення). Через 3 год від уведення флогогену ПБЧ дещо зростав, водночас залишався нижчим за вихідне значення на $15-24 \%$.

Результат дії Кеторолаку був передбачуваним - статистично значиме зростання ПБЧ на $51 \%$ і на $62 \%$ через 4 та 24 год відповідно після введення формаліну, що свідчить про суттєву аналгетичну активність цього препарату (рисунок).

У разі застосування Гідазепаму відзначалося суттєве $(\mathrm{p}<0,05)$ зростання

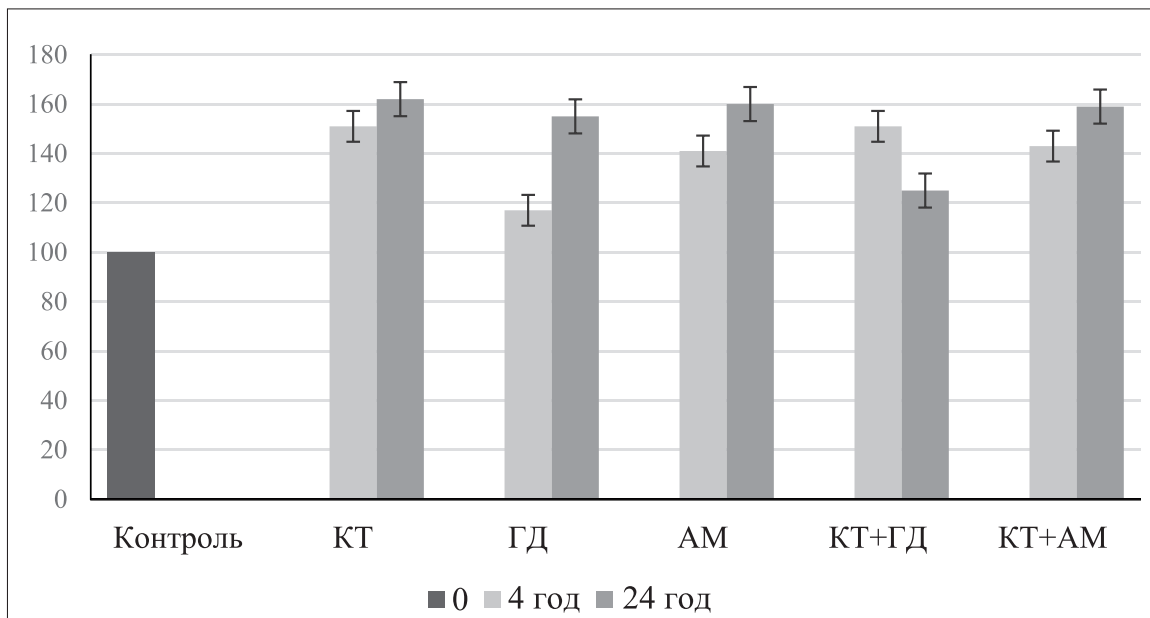

Рисунок. Поріг больової чутливості за дї̈ Гідазепалу, Алітриптиліну та за їхнього комбінованого застосування з Кеторолаком на тлі больового синдрому, \%

Примітка. КТ, ГД, АМ - кеторолак, гідазепам, амітриптилін відповідно. 
ПБЧ на $17 \%$ і на $55 \%$ через 4 год та 24 год відповідно після введення транквілізатору. Тобто, знеболювальна дія Гідазепаму була значно нижчою за дію Кеторолаку через 4 год від індукції запалення. Більш значущим за дію Гідазепаму через 4 год від уведення формаліну був антиноцицептивний вплив Амітриптиліну. За його використання больове відчуття в білих щурів знизилося на 41 і $60 \%$ через 4 та 24 год відповідно після індукції больової реакції (рисунок). Отримані дані можуть бути свідченням прояву антиноцицептивної дії нейротропних препаратів Гідазепаму та Амітриптиліну. Фактично, антиноцицептивна активність Гідазепаму та Амітриптиліну є співставною 3 дією аналгетика через 24 год від уведення формаліну.

Комбіноване застосування Кеторолаку з Гідазепамом призводило до зростання ПБЧ, як і за самостійного застосування Кеторолаку, на $51 \%$ через 4 год від індукції больової реакції. Водночас за взаємодії цих препаратів через 24 год значно зросло больове відчуття в тварин, про що свідчило зниження ПБЧ на $37 \%$ і на $30 \%$ порівняно до значень, що реєструвалися за самостійного застосування Кеторолаку та Гідазепаму відповідно. Можливо даний результат зумовлений фармакокінетичною взаємодією Кеторолаку з Гідазепамом та/або не вивченими механізмами взаємодії цих препаратів.

Амітриптилін за комбінованого застосування з Кеторолаком дещо знижував антиноцицептивну активність останнього через 4 год і не впливав на його активність через 24 год від індукції больової реакції.

Таким чином, транквілізатору Гідазепаму та антидепресанту Амітриптиліну за самостійного застосування на тлі больового синдрому притаманна антиноцицептивна дія. Вона є більш вираженою в Амітриптиліну. Антидепресант не впливає на знеболювальну активність Кеторолаку, а Гідазепам дещо зменшує ії через 24 год від індукції запалення за комбінованого застосування з Кеторолаком. Даний результат може бути свідченням відсутності наслідків фармакодинамічної взаємодії
Кеторолаку 3 Амітриптиліном щодо змін антиноцицептивної активності цих препаратів.

За дослідження розвитку набряку встановлено, що флогоген формалін спричинив суттєве підвищення на $36 \%$ i на $39 \%$ досліджуваного показника через 4 год і через 24 год після індукції запалення відповідно, тоді як вихідне значення об'єму стопи в щурів становило $(1,13 \pm 0,04)$ ум. од. (табл. 1$)$.

Результати досліджень протинабрякової дії нейротропних засобів на моделі запальної реакції, спричиненої формаліном, засвідчили, що Гідазепам сприяв зменшенню об'єму стопи в щурів із запальною реакцією порівняно 3 аналогічним показником у групі контрольних тварин, що свідчить про слабку протизапальну дію Гідазепаму. Амітриптилін не призводив до зменшення об'єму стопи в щурів, а навпаки збільшував набряк кінцівок у щурів у різні терміни спостереження порівняно 3 показником у тварин контрольної групи. Даний результат є свідченням відсутності протинабрякової дії в Амітриптиліну.

Кеторолак суттєво зменшував набряк кінцівки в щурів (на $15 \%$ і на $13 \%$ через 4 та через 24 год відповідно) порівняно до даних, що реєструвалися в групі контрольних тварин, що свідчить про його протинабрякову (протизапальну) дію (табл. 1).

За комбінованого застосування Гідазепаму з Кеторолаком зменшувалася протинабрякова дія Кеторолаку, а застосування Амітриптиліну з Кеторолаком, фактично, нівелювало протинабрякову дію останнього, і Амітриптилін посилював набряк, про що свідчить збільшення об'єму кінцівки в щурів на (35-10) \% у різні відмітки часу порівняно з аналогічним показником у тварин, які отримували лише Кеторолак. Крім того, Амітриптилін за комбінованого застосування з Кеторолаком сприяв ще більш суттєвому збільшенню набряку за той, що реєструвався в групі контролю через 4 год від індукції запалення.

Здійснено вивчення впливу Гідазепаму та Амітриптиліну на стан структурно-динамічної організації мембран 
Таблиця 1

Об’ем стопи в білих щурів за колбінованого застосування Гідазепалу й Алітриптиліну з Кеторолакол на моделі форлалінового запалення, ул. од.

\begin{tabular}{|c|c|c|}
\hline Вихідне значення & Через 4 год & Через 24 год \\
\hline \multicolumn{3}{|c|}{ Контроль - формалін, 2 \% розчин $(n=16)$} \\
\hline $1,13 \pm 0,04$ & $1,54 \pm 0,06^{*}$ & $1,57 \pm 0,10^{*}$ \\
\hline Відсоток змін & +36 & +39 \\
\hline \multicolumn{3}{|c|}{ Гідазепам, 0,02 мг/кг + формалін $(n=8)$} \\
\hline $1,14 \pm 0,04$ & $1,32 \pm 0,10^{\star}$ & $1,45 \pm 0,09^{\star}$ \\
\hline Відсоток змін & +16 & +27 \\
\hline \multicolumn{3}{|c|}{ Амітриптилін, 16 мг/кг + формалін $(n=8)$} \\
\hline $1,09 \pm 0,10$ & $1,64 \pm 0,02^{\star}$ & $1,63 \pm 0,07^{*}$ \\
\hline Відсоток змін & +51 & +50 \\
\hline \multicolumn{3}{|c|}{ Кеторолак, 1,5 мг/кг + формалін $(n=16)$} \\
\hline $1,08 \pm 0,04$ & $1,31 \pm 0,05^{\star, \#}$ & $1,36 \pm 0,02^{\star, \#}$ \\
\hline Відсоток змін & +21 & +26 \\
\hline \multicolumn{3}{|c|}{ Кеторолак, 1,5 мг/кг + Гідазепам, 0,02 мг/кг + формалін ( $n=8)$} \\
\hline $1,10 \pm 0,04$ & $1,43 \pm 0,10^{\star}$ & $1,47 \pm 0,10^{\star}$ \\
\hline Відсоток змін & +30 & +34 \\
\hline \multicolumn{3}{|c|}{ Кеторолак, 1,5 мг/кг + Амітриптилін, 16 мг/кг + формалін $(n=8)$} \\
\hline $1,10 \pm 0,04$ & $1,71 \pm 0,05^{\star}, \#$ & $1,49 \pm 0,07^{*}$ \\
\hline Відсоток змін & +56 & +36 \\
\hline
\end{tabular}

Прилітка. *p < 0,05 порівняно з вихідния значеннял показника в тварин кожної групи, ${ }^{\#} p<0,05$ порівняно з показникол у тварин контрольної групи.

еритроцитів за умов комбінованого застосування 3 Кеторолаком на тлі гострого больового синдрому. Константа зв'язування аніонного зонда AНC із мембраною еритроцитів може характеризувати спорідненість поверхні мембрани до зонда, наявність заряду на його поверхні. Результати флуоресцентного зондування суспензій еритроцитів зондом АНC наведено в таблиці 2.

У разі розвитку гострого больового синдрому через 4 год від уведення флогогену константа зв'язування зонда АНС з мембраною еритроцитів зростала та залишалася на тому самому рівні через 24 год, що свідчить про зміни властивостей поверхні мембрани, які призводять до збільшення її позитивного заряду. На тлі введеного Гідазепаму, так само і Кеторолаку, відзначалося зростання зв'язування через 4 год, а потім зменшення (через 24 год) навіть нижче рівня, виявленого для інтактних тварин.
Подібні процеси мали місце й у разі розвитку больового синдрому на тлі комбінованого введення Кеторолаку та Гідазепаму, через 24 год $\kappa_{\text {зв }}$ майже не відрізнялася від показників інтактних тварин. Тобто, як за самостійного застосування Гідазепаму та Кеторолаку, так i за комбінованого застосування цих препаратів виявлялася захисна дія щодо структури поверхні мембран еритроцитів, що характеризувалася запобіганням збільшення позитивного заряду, яке спостерігалося за гострого больового синдрому.

Достовірних змін властивостей поверхні мембран еритроцитів за дії Амітриптиліну, комбінованого введення Кеторолаку та Амітриптиліну не було зареєстровано.

У процесі флуоресцентного зондування суспензій еритроцитів піреном $\left(\mathrm{Cp}=5 \cdot 10^{-6}\right.$ моль/л) методом IPПЕ вивчали вірогідність переносу енергії з молекул протеїнів (донорів) на флуоресцентний зонд пірен (акцептор) [18]. 
Таблиця 2

Константи з6'язування зонда АНС із мембранами еритроцитів щурів за умов гострого больового синдрому й застосування Гідазепаму,

Алітриптиліну та Кеторолаку

\begin{tabular}{|c|c|}
\hline Група тварин & $\begin{array}{c}\text { АНС, } \mathrm{K}_{\text {зв}}, \\
10^{-4} \text { моль/л }\end{array}$ \\
\hline Інтактні & $0,869 \pm 0,032$ \\
\hline \multicolumn{2}{|c|}{4 год після введення формаліну } \\
\hline Контроль & $0,947 \pm 0,018^{*}$ \\
\hline Кеторолак & $0,955 \pm 0,056$ \\
\hline Гідазепам & $0,965 \pm 0,039$ \\
\hline Кеторолак + Гідазепам & $1,055 \pm 0,110^{*}$ \\
\hline \multicolumn{2}{|c|}{24 год після введення формаліну } \\
\hline Контроль & $0,946 \pm 0,026$ \\
\hline Кеторолак & $0,836 \pm 0,014^{\#}$ \\
\hline Гідазепам & $0,839 \pm 0,021^{\#}$ \\
\hline Кеторолак + Гідазепам & $0,870 \pm 0,022^{\#}$ \\
\hline Амітриптилін & $0,881 \pm 0,050$ \\
\hline Кеторолак + Амітриптилін & $0,940 \pm 0,130$ \\
\hline
\end{tabular}

Примітка. Тут і в табл. 3: *p <0,05 порівняно з показником в інтактних тварин, ${ }^{\#} p<0,05$ порівняно з показником у тварин контрольної групи (формаліновий набряк).

Показник вірогідності IPПЕ характеризує середню відстань між донором та акцептором (протеїн-пірен) у мембрані еритроциту. Пірен локалізований переважно в ліпідній частині мембрані, тому індуктивно-резонансний перенос енергії має місце переважно 3 інтегральними протеїнами. У разі зменшення відстані зростає протеїнліпідний контакт, збільшується показник W, і навпаки - показник зменшується в разі збільшення відстані донор-акцептор.

Визначено, що в процесі розвитку гострого больового синдрому вірогідність IPПЕ поступово зростала (4 год і 24 год), що може свідчити про зменшення відстані між інтегральними протеїнами та молекулами зонда пірену, тобто, про збільшення щільності мембрани (табл. 3).

Можливо, що монотонне зростання вірогідності IPПЕ пов'язане з процесами ПОЛ, які призводять до змін у ліпідах бішару, а потім до зменшення від- стані інтегральний протеїн-пірен. Больовий синдром на тлі введеного Кеторолаку через 4 год призводив до ще більш різкого збільшення $\mathrm{W}, \mathrm{a}$ через 24 год - до зменшення значення вірогідності IPПЕ. Тобто, патологічна ущільненість мембрани зменшувалася. Подібні тенденції спостерігалися за дії Гідазепаму та комбінованого застосування Кеторолаку з Гідазепамом. Через 24 год після індукції запалення значення показника W для групи тварин 3 больовим синдромом перевищувало значення цього показника для груп тварин, у яких розвивалася патологія на тлі введеного Кеторолаку, Гідазепаму, або Кеторолаку з Гідазепамом. Таким чином, досліджувані лікарські засоби виявляли захисну дію щодо глибинних гідрофобних ланок ліпідного бішару мембрани еритроцитів уже через 24 год.

Достовірних змін щодо взаємного розташування інтегральних протеїнів і ліпідів за умов застосування Амітриптиліну окремо та за комбінованого застосування антидепресанту з Кеторолаком на тлі гострого больового синдрому не виявлено.

Отже, отримані результати свідчать, що в процесі розвитку больового синдрому, індукованого формаліном,

Таблиця 3

Вірогідність індуктивно-резонансного переносу енергї в мембранах еритроцитів щурів на тлі гострого больового синдрому та застосування Гідазепаму й Кеторолаку

\begin{tabular}{|l|c|}
\hline \multicolumn{1}{|c|}{ Група тварин } & $\begin{array}{c}\text { Biporiдність } \\
\text { IPПE, W, ум. од. }\end{array}$ \\
\hline Інтактні & $0,210 \pm 0,011$ \\
\hline \multicolumn{2}{|c|}{4 год після введення формаліну } \\
\hline Контроль & $0,246 \pm 0,027$ \\
\hline Кеторолак & $0,304 \pm 0,016^{\star}$ \\
\hline Гідазепам & $0,312 \pm 0,015^{\star}$ \\
\hline Кеторолак + Гідазепам & $0,284 \pm 0,009^{\star}$ \\
\hline \multicolumn{2}{|c|}{24 год після введення формаліну } \\
\hline Контроль & $0,287 \pm 0,021^{\star}$ \\
\hline Кеторолак & $0,238 \pm 0,014^{\star}, \#$ \\
\hline Гідазепам & $0,261 \pm 0,011^{\star}$ \\
\hline Кеторолак + Гідазепам & $0,269 \pm 0,017^{\star}$ \\
\hline
\end{tabular}


у мембранах еритроцитів відбуваються зміни структури, що спричинюють зростання позивного заряду поверхні мембрани та збільшення щільності глибинних гідрофобних ланок мембрани. За введення Гідазепаму, Кеторолаку, а також за їхнього комбінованого застосування, через 24 год від індукції запального процесу, що супроводжується больовим синдромом, змін заряду поверхні мембрани, що притаманні патологічному процесу, не зафіксовано. Гідазепам і Кеторолак як за самостійного, так і за комбінованого застосування призводять до зменшення ущільнення структури глибинних гідрофобних ланок ліпідного бішару мембран еритроцитів. Тобто, Гідазепам і Кеторолак, на відміну від Амітриптиліну, виявляють захисну дію щодо структури поверхні мембран еритроцитів і глибинних її гідрофобних ланок.

Результати проведених досліджень свідчать про наявність фармакодинамічної взаємодії між лікарськими засобами різних фармакотерапевтичних груп, зокрема - НПЗП і транквілізаторами та антидепресантами на тлі гострого больового синдрому. Усі можливі механізми цієї взаємодії наразі невідомі та потребують спеціальних досліджень. Водночас можна припустити, що комбіноване застосування Кеторолаку з Гідазепамом і Кеторолаку 3 Амітриптиліном можливе (за необхідності коригування діяльності центральної нервової системи) як таке, що не призводить до нівелювання аналгезуючої дії Кеторолаку. Водночас досягнути необхідного ефекту щодо зменшення набряків у разі застосування зазначених комбінацій лікарських засобів на тлі запального процесу, вочевидь, неможливо. Збільшення набряків за умов застосування Амітриптиліну було прогнозованим через затримку води в організмі, здатність препарату викликати набряки обличчя, язика, яєчок тощо.

За результатами досліджень можна припустити, що механізм знеболювальної дії антидепресанту (Амітриптиліну) не опосередкований взаємодією з периферичними ноцицепторами, a зумовлений центральними впливами. Знеболювальна дія транквілізатора, можливо, певною мірою опосередковується впливом на центральні структури та взаємодією з периферичними рецепторами. Однією з ланок патогенезу больового синдрому, вочевидь, $є$ порушення структурно-динамічних властивостей мембран (еритроцитів, зокрема). Прослідковується певний зв'язок між мембраностабілізуючим впливом Кеторолаку та Гідазепаму 3 протинабряковою дією цих препаратів, тоді як для Амітриптиліну виявилися характерними пронабрякова дія та відсутність позитивного впливу на структурно-динамічні характеристики мембран на даній моделі запального процесу.

\section{Висновки}

1. Гідазепаму й Амітриптиліну властива знеболювальна дія на тлі больового синдрому, спричиненого введенням формаліну, водночас, вони не впливають на протибольову активність Кеторолаку й їхня власна аналгетична активність не змінюеться за комбінованого застосування з Кеторолаком порівняно з показником за умов монотерапії транквілізатором чи антидепресантом.

2. Кеторолаку притаманна протинабрякова (протизапальна) активність за умов больового синдрому, індукованого хімічним агентом. Гідазепам сприяє зменшенню, а Амітриптилін - посиленню набряку як за самостійного, так і за комбінованого застосування з Кеторолаком.

3. Гідазепам і Кеторолак за окремого та комбінованого застосування виявляють мембраностабілізуючі властивості, про що свідчить зниження константи зв'язування зонда АНC 3 мембраною еритроцитів до норми через 24 год від генерації патології. Ці лікарські засоби також виявляють захисну дію щодо структури глибинних гідрофобних ланок мембран еритроцитів, зменшуючи їхне патологічне ущільнення.

4. Комбіноване застосування Кеторолаку з Гідазепамом і Кеторолаку з Амітриптиліном можливе (за необхід- 
ності коригування діяльності центральної нервової системи) як таке, що не призводить до нівелювання аналгезуючої дії Кеторолаку. Отримані знання можуть бути враховани- ми для створення нових та оптимізації існуючих схем застосування аналгетиків та ад'ювантних лікарських засобів за больового синдрому хімічного генезу.

1. Charles E. Argoff M. D. Gary Mc Cleane Pain Management Secrets. Mosby/Elsevier. 2009. 408 p. https://doi.org/10.1016/B978-0-323-04019-8.X0001-7.

2. Вальдман А. В. Боль как эмоционально-стрессовая реакция. Вестник АМН СССР. 1980. № 9. C. $11-17$.

3. Пилипович А. А., Данилов А. В. Дифференцированный подход к терапии боли: роль нестероидных противовоспалительных препаратов. РМЖ. 2013. Т. 115, № 12. С. 98-103.

4. Effectiveness of pregabalin for thetreatment of chronic low back pain with accompanying lower limb pain (neuropathic component): a non-interventional study in Japan. T. Taguchi, A. Igarashi, S. Watt et al. J PainRes. 2015. № 8. P. 487-497.

5. Attal N., Bouhassira D. Pharmacotherapy of neuropathic pain: which drugs, which treatment algorithms? Pain. 2015. V. 156, Suppl 1. S. 104-142.

6. Губський Ю. І., Хобзей М. К. Фармакотерапія в паліативній та хоспісній медицині. Київ : «Здоров'я», 2011. 352 с.

7. Имаметдинова Г. Р., Чичасова Н. В., Иголкина Е. В. Подходы к лечению боли с учетом механизмов ее развития. Современная ревматология. 2013. № 1. C. 59-65. https://doi. org/10/14412/1996-7012/2013/2370.

8. Викторов А. П. Фармакотерапия хронической боли: проблемы эффективности и безопасности. Фармакотерапия при хронической боли (Часть 1). Провизор. 2009. Вып. 6. С. 9-14.

9. Якупов Э. З., Якупова С. П., Муслимова Е. А. Мультивекторный характер купирования острой и хронической боли и необходимость использования копинг-стратегий ее преодоления. Журнал неврологии и психиатрии им. С. С. Корсакова. 2015. Т. 115, № 12. С. 98-103. https://doi. org/10/17116/jnevro201511511298-103.

10. Дубенко А. Е., Коростий В. И. Общие принципы лечения хронической боли у пожилых пациентов. НейроNews: психоневрология и нейропсихиатрия. 2017. № 1. С. 18-23.

11. Патопсихологические аспекты болевых синдромов в нижней части спины. А. И. Крупаткин, А. А. Кулешов, Т. В. Соколова, А. О. Господ. Журнал неврологии и психиатрии. 2017. № 4. C. 102-106. https://doi.org/10/17116/jnevro201711711741102-106.

12. Бурчинский С. Г. Роль и место бензодиазепинов в фармакотерапии посттравматического стрессового расстройства. Международный неврологический журнал. 2018. № 4. С. 68-74. http://nbuv.gov.ua/UJRN/Mnzh_2018_4_12.

13. Бурчинский С. Г. Бензодиазепины в фармакотерапии тревожных состояний. Журнал неврології ім. Б. М. Маньковського. 2018. Т. 6, № 1. С. 46-54.

14. Кудрин В. С., Бледнов Ю. А., Лапицкая А. С. Влияние гидазепама на содержание моноаминов в мозге мышей линии BALB/C. Экспериментальная и клиническая фармакология. 1998. № 4. С.12-13.

15. Лапицкая A. С. Сравнительное исследование нейрохимических эффектов гидазепама и феназепама. Дис. канд. биол. наук, специальность по ВАК РФ 14.00.25. Москва, 2000. 143 с.

16. Антиоксидантні властивості гідазепаму й амітриптиліну за больового синдрому у щурів. Ю. І. Губський, Н. М. Серединська, Т. А. Бухтіарова, Л. П. Бабенко. Фармацевтичний журнал. 2019. № 4. С. 88-95. https://doi: 10/32353/0367-3057/4/19/10.

17. Владимиров Ю. А., Добрецов Г. Е. Флуоресцентные зонды в исследовании биологических мембран. Москва : Наука, 1980. 277 с.

18. Добрецов Г. Е. Флуоресцентные зонды в исследовании клеток, мембран и липопротеинов. Москва : Наука, 1989. 274 с.

19. Біофізичні властивості мембран еритроцитів та механізми взаємодії з ненаркотичними аналгетиками в умовах гострого больового синдрому. Ю. І. Губський, Т. А. Бухтіарова, Г. Г. Горюшко та ін. Український біохімічний журнал. 2014. Т. 86, № 3. С. 98-106.

\section{Н. М. Серединська, Т. А. Бухтіарова, Л. П. Бабенко, О. М. Величко Модуляція протизапальної активності Кеторолаку за умов фармакодинамічної взаємодії з Гідазепамом й Амітриптиліном і структурно-динамічні властивості мембран еритроцитів на тлі больового синдрому}

Численні патологічні стани супроводжуються больовим синдромом, що потребує фармакологічної корекції. 3 метою посилення ефективності, зокрема, нестероїдних протизапальних засобів як знеболювальних і протизапальних препаратів нерідко застосовують препарати допоміжної 
(ад'ювантної) терапії. Зважаючи на можливі психоемоційні розлади та порушення цілісності мембран, що можуть спостерігатися за больового синдрому, слід з'ясувати, чи доцільне застосування транквілізаторів та/або антидепресантів з аналгезуючими препаратами з метою зменшення проявів запалення та для покращання структурно-динамічних властивостей мембран клітин.

Мета дослідження - вивчити аналгезуючу, протизапальну та мембраностабілізуючу дію денного транквілізатора Гідазепаму та класичного трициклічного антидепресанту Амітриптиліну на тлі больового синдрому за умов комбінованого застосування з ненаркотичним аналгетиком Кеторолаком.

Результати проведених досліджень свідчать про наявність фармакодинамічної взаємодії між нестероїдними протизапальними препаратами та транквілізаторами й антидепресантами на тлі гострого больового синдрому. Гідазепаму та Амітриптиліну властива знеболювальна дія на тлі больового синдрому, спричиненого введенням формаліну, водночас вони не впливають на протибольову активність Кеторолаку й їхня власна аналгетична активність не змінюється за комбінованого застосування з Кеторолаком порівняно з монотерапією транквілізатором чи антидепресантом.

Кеторолаку притаманна протинабрякова (протизапальна) активність за умов больового синдрому, індукованого хімічним агентом. Гідазепам сприяє зменшенню, а Амітриптилін - посиленню набряку як за самостійного, так і за комбінованого застосування з Кеторолаком.

Гідазепам і Кеторолак за окремого й комбінованого застосування виявляють мембраностабілізуючі властивості, про що свідчить зниження константи зв'язування зонда АНС з мембраною еритроцитів до норми та захисна дія щодо структури глибинних гідрофобних ланок мембран еритроцитів. Амітриптиліну не притаманний позитивний вплив на структурно-динамічні характеристики мембран на даній моделі запального процесу.

Отримані знання можуть бути врахованими за створення нових та оптимізації існуючих схем застосування аналгетиків та ад'ювантних лікарських засобів за больового синдрому хімічного генезу.

Ключові слова: больовий синдром, Кеторолак, Гідазепам, Амітриптилін, протизапальна дія, мембрани еритроцитів

\section{Н. Н. Серединская, Т. А. Бухтиарова, Л. П. Бабенко, А. Н. Величко Модуляция противовоспалительной активности Кеторолака при фармакодинамическом взаимодействии с Гидазепамом и Амитриптилином и структурно-динамические свойства мембран эритроцитов на фоне болевого синдрома}

Многочисленные патологические состояния сопровождаются болевым синдромом, который требует фармакологической коррекции. С целью усиления эффективности, в частности, нестероидных противовоспалительных средств как обезболивающих и противовоспалительных препаратов, часто применяют препараты вспомогательной (адъювантной) терапии. Принимая во внимание возможные психоэмоциональные расстройства и нарушения целостности мембран, которые могут наблюдаться при болевом синдроме, необходимо исследовать, целесообразно ли применение транквилизаторов и/или антидепрессантов с анальгезирующими препаратами с целью уменьшения симптомом воспаления и улучшения структурно-динамических свойств мембран клеток.

Цель исследования - изучить анальгезирующее, противовоспалительное и мембраностабилизирующее действие дневного транквилизатора Гидазепама и классического трициклического антидепрессанта Амитриптилина на фоне болевого синдрома при комбинированном применении с ненаркотическим аналгетиком Кеторолаком.

Результаты проведенных исследований свидетельствуют о фармакодинамическом взаимодействии между нестероидными противовоспалительными препаратами и транквилизаторами, антидепрессантами на фоне острого болевого синдрома. Гидазепаму и Амитриптилину свойственна обезболивающая активность при болевом синдроме, индуцированном введением формалина. Гидазепам и Амитриптилин не влияют на противоболевую активность Кеторолака и их собственная анальгетическая активность не изменяется при комбинированном применении с Кеторолаком по сравнению с монотерапией транквилизатором или антидепрессантом.

Кеторолаку присуще противоотечное (противовоспалительное) действие при болевом синдроме, индуцированном химическим агентом. Гидазепам способствует уменьшению, а Амитриптилин - усилению отека как при самостоятельном, так и при комбинированном применении с Кеторолаком.

Гидазепам и Кеторолак при самостоятельном и комбинированном использовании проявляют мембраностабилизирующее действие, о чем свидетельствует снижение константы связывания зонда АНС с мембраной эритроцитов до нормы и защитное действие относительно структуры глубинных гидрофобных звеньев мембран эритроцитов. Амитриптилину не свойственно положительное влияние на структурно-динамические характеристики мембран на данной модели воспаления.

Полученные знания могут быть учтены при разработке новых и оптимизации существующих схем применения анальгетиков и адъювантных лекарственных средств при болевом синдроме химического генеза.

Ключевые слова: болевой синдром, Кеторолак, Гидазепам, Амитриптилин, противовоспалительное действие, мембраны эритроцитов 


\section{N. N. Seredinskaya, T. A. Bukhtiarova, L. P. Babenko, A. N. Velichko \\ Modulation of the anti-inflammatory activity of Ketorolac under pharmacodynamic interaction with Gidazepam and Amitriptyline and structural-dynamic properties of erythrocyte membranes at pain syndrom}

Numerous pathological conditions are accompanied by pain, which requires pharmacological correction. In order to enhance the effectiveness of, in particular, non-steroidal anti-inflammatory drugs as analgesic and anti-inflammatory drugs, adjuvant therapy is often used. Taking into account possible psycho-emotional disorders and membrane integrity disorders that can be observed with pain, it is necessary to investigate whether it is advisable to use tranquilizers and/or antidepressants with analgesics to reduce the symptom of inflammation and to improve the structural and dynamic properties of cell membranes.

The purpose of the study - to investigate the analgesic, anti-inflammatory and membrane-stabilizing effect of the daily tranquilizer Gidazepam and the classic tricyclic antidepressant Amitriptyline when combined with the non-narcotic analgesic Ketorolac at pain syndrom.

The results of the study indicate a pharmacodynamic interaction between non-steroidal antiinflammatory drugs and tranquilizers and antidepressants at acute pain. Gidazepam and Amitriptyline are characterized by analgesic activity in the pain syndrome induced by the introduction of formalin. Gidazepam and Amitriptyline do not affect the analgesic activity of Ketorolac and their own analgesic activity does not change when combined with Ketorolac compared with monotherapy by tranquilizer and antidepressant.

Ketorolac has an antiedemic (anti-inflammatory) effect in the pain syndrome induced by a chemical agent. Gidazepam helps to reduce, and Amitriptyline - enhances edema, both in monotherapy and combined use with Ketorolac.

Gidazepam and Ketorolac, when used singly and when combined, exhibit a membrane-stabilizing effect, as evidenced by a decrease in the binding constant of the ANS probe- in erythrocyte membrane to the norm and a protective effect on the structure of deep hydrophobic links of erythrocyte membranes. Amitriptyline does not have a positive effect on the structural-dynamic characteristics of membranes in this model of inflammation.

The knowledge gained can be taken into account when developing new and optimizing existing regimens for the use of analgesics and adjuvant drugs under pain syndrome of chemical genesis.

Key words: pain syndrome, Ketorolac, Gydazepam, Amitriptyline, anti-inflammatory effect, erythrocyte membranes

Прийнята до друку: 22 квітня 2020 р.

Контактна особа: Серединська Н. М., доктор медичних наук, відділ фармакології, ДУ «Інститут фармакології та токсикології НАМНУ», буд. 14, вул. Антона Цедіка, м. Київ, 03057. Тел.: + 380444568472 